\title{
Possible roles of local oviductal estradiol-17 $\beta$ in luteal formation phase on the function of bovine oviductal epithelium
}

\author{
Ken HAZANO ${ }^{1,2)}$, Shingo HANEDA ${ }^{2)}$, Mitsunori KAYANO ${ }^{3)}$ and \\ Motozumi MATSUI')* \\ 1)The United Graduate School of Veterinary Sciences, Gifu University, 1-1 Yanagido, Gifu 501-1193, Japan \\ 2) Department of Veterinary Medicine, Obihiro University of Agriculture and Veterinary Medicine, Inada-cho, \\ Obihiro, Hokkaido 080-8555, Japan \\ ${ }^{3)}$ Graduate School of Animal and Food Hygiene, Obihiro University of Agriculture and Veterinary Medicine, \\ Inada-cho, Obihiro, Hokkaido 080-8555, Japan
}

J. Vet. Med. Sci.

81(12): 1817-1823, 2019

doi: 10.1292/jvms.19-0411

Received: 25 July 2019

Accepted: 1 October 2019

Advanced Epub:

31 October 2019
ABSTRACT. Oviducts play an important role in the reproductive process, such as in gamete transport, fertilization, and early embryonic development. However, the regulation of oviductal function during luteal formation phase (3-5 days post-ovulation), which is a crucial phase for early embryonic development, remains poorly understood. This study investigated the roles of oviductal estradiol-17 (E2) and progesterone (P4) concentrations on bovine oviductal functions in the luteal formation phase using RT-qPCR for some genes of oviductal epithelial cells. Bovine oviducts ipsilateral to the corpus luteum $(\mathrm{CL})$ in the luteal formation phase were collected from a slaughterhouse. The concentration of oviductal E2 was positively correlated with the mRNA expressions of nuclear P4 receptor $(P G R)$ and protein disulfide isomerase family A member 4 (PDIA4), which is related to protein secretion, in the ampulla and with estrogen receptor a (ESR1) mRNA expression in the isthmus. In contrast, the concentration of oviductal P4 was not correlated with oviductal mRNA expressions in either regions. Furthermore, for the candidate factor related to the oviductal E2 concentration, the CL parameters (CL size and tissue P4 concentration), firstwave dominant follicle (W1DF) parameters (follicle size and intrafollicular E2 concentration), and W1DF location (ipsilateral or contralateral to $\mathrm{CL}$ ) did not influence the oviductal E2 concentration. In conclusion, our results suggest that the local oviductal E2 is a potential oviductal function regulator during the luteal formation phase.

KEY WORDS: bovine, estradiol, follicle, oviduct

In cattle, oviducts play an important role in the reproductive process, owing to their involvement in gamete transport, fertilization, and early embryonic development $[2,20]$. For example, the oviductal mucosa produced by oviductal epithelial cells comprises various metabolic substrates and proteins, which promote fertilization and early embryonic development $[9,20]$. The oviduct comprises three anatomic regions - infundibulum, ampulla and isthmus - that have different roles in the reproductive processes. The infundibulum collects the cumulus-oocyte complex (COC) at ovulation whereas the ampulla transports the COC to the ampullary-isthmic junction, where fertilization occurs. The isthmus constitutes the environment for early embryonic development [2]. It was previously reported that the morphology of oviductal epithelium is different in these three regions [32]. In addition, the functions of ampulla and isthmus have been extensively investigated and shown to differ [21].

In cattle, the embryo remains in the oviduct for 4-5 days post-fertilization [2] and the oviductal function during this time is considered crucial for early embryonic development. Oviductal functions are known to be regulated by sex steroid hormones [5]. A previous study using a manipulated growth model of cow's pre-ovulatory follicle showed that the different endocrine milieu that occurred during the peri-ovulatory period influenced the morphological and functional features of bovine oviducts at four days post-ovulation $[11,12]$. In the follicular phase, the volume of oviductal fluid increases with a high systemic level of estradiol-17 $\beta$ (E2) [16]. In addition, oviductal glycoprotein 1 (OVGP1), heat shock protein 90 beta family member 1 (HSP90B1), glutathione peroxidase 4 (GPX4), and protein disulfide isomerase family A member 4 (PDIA4), known as the genes of bovine oviductal cells, were previously reported to be upregulated in the follicular phase $[4,19]$. It is known that OVGP1 interacts with the oocyte, sperm, and embryo [5]; HSP9OB1 and PDIA4 are related to some biological process (i.e., protein secretion and stress response) [4]; and 
GPX4 plays a role of protection against embryo stress $[5,20]$. These reports suggest that E2 has the crucial role of regulating oviductal functions during the follicular phase.

In cattle, the increase of plasma E2 concentration was observed between 3- and 9-days post-estrus. This E2 peak is smaller than that of the follicular phase [7, 10, 25]. During 4-5 days post-ovulation, a dominant follicle of the first follicular wave (W1DF) grows in the ovary concomitantly with the luteal formation. This follicle is considered to be a reason for the post-estrous E2 peak. It is known that in follicular phase, the local E2 concentration in the ipsilateral oviduct to the pre-ovulatory follicle is higher than that in the contralateral oviduct [31]. Therefore, the location and function of W1DF may influence the oviductal E2 concentration in the luteal formation phase. In cattle, the high peripheral blood E2 concentration that occurs between 3 and 14 days postovulation is associated with low fertility $[3,23]$. These reports suggest that the high plasma E2 level due to W1DF in the luteal formation phase impairs conception in cattle.

However, the effects of the location of W1DF and the increase in plasma E2 concentration between 3 and 9 days post ovulation on oviductal the E2 concentration and function still require clarifications. To clarify the relationship between E2 and oviductal function in the luteal formation phase, this study examined (i) the effect of the location of W1DF and the ovarian function on oviductal E2 concentration and (ii) the relationship between the oviductal E2 concentration and the abundance of steroid hormone receptor transcripts and some functional genes of bovine oviductal epithelium in the luteal formation phase.

\section{MATERIALS AND METHODS}

\section{Tissue collection}

This study was approved by the Animal Experiment Committee of Obihiro University of Agriculture and Veterinary Medicine, Japan. The oviducts of healthy parous cows were collected at a local slaughterhouse within 30 min after slaughter, immediately placed into ice-cold $0.9 \%$ saline solution (Otsuka Chemical, Tokyo, Japan), and transported to the laboratory. The stage of the estrous cycle was estimated by examining the ovaries (i.e., follicles and CL) and uterus, according to previously described criteria $[1,13]$. After such examination, the oviducts predicted to be in the luteal formation phase (3-5 days post-ovulation) were selected. In general, only one healthy follicle is selected as W1DF by follicle deviation from 3 to 5 days post-ovulation [10]. To confirm the existence of an active W1DF, its intrafollicular E2 and progesterone (P4) concentrations were measured. The reproductive tracts that presented W1DF with a concentration ratio of E2: P4 higher than 1 were used for this experiment. The reproductive tracts were classified into two groups depending on the positional relationship between CL and W1DF within the ovary: ipsilateral (ipsi: CL and W1DF exist in the same ovary, $\mathrm{n}=8$ ) and contralateral (contra: $\mathrm{CL}$ and W1DF exist in different ovaries, $\mathrm{n}=8$ ) groups. Moreover, the $\mathrm{CL}$ diameter was measured and the $\mathrm{CL}$ tissue was stored at $-30^{\circ} \mathrm{C}$ following snap freezing in liquid nitrogen for the hormone assay.

In this study, to examine the oviduct, which is the environment for embryonic development, oviducts in the CL side were used for the experiments (total: $n=16$; ipsi: $n=8$; and contra: $n=8$ ). Following the removal of the connective tissues, blood vessels, and adhering fats, the oviducts were cut into two regions (i.e., ampulla and isthmus) as previously described [17]. The infundibulum and ampulla-isthmus transition were discarded with sufficient margin. Each region was divided into two pieces and the epithelial cells were collected from one piece, as previously described [30]. Briefly, a slide glass was pressed from above the oviduct tissue placed on a petri dish and the oviductal epithelial cells were mechanically dislodged in a gently squeezed state. The oviductal epithelial cells were put into ISOGEN II (NIPPON GENE, Tokyo, Japan), snap-frozen in liquid nitrogen, then stored at $-80^{\circ} \mathrm{C}$ until total RNA isolation.

The remaining piece was directly snap-frozen in liquid nitrogen and stored at $-30^{\circ} \mathrm{C}$. Subsequently, it was used to make homogenized samples from the frozen tissues, as previously described [28]. The frozen tissues were placed into a glass tube containing $0.9 \%$ physiological saline (100 mg tissue per $1 \mathrm{~m} l$ saline solution) and homogenized (AHG-169A; AS ONE, Osaka, Japan) at 13,500 rpm with the glass tube placed in ice-cold water until the tissues were completely homogenized. The homogenized samples were centrifuged at $1,400 \times \mathrm{g}$ for 5 min and the supernatants were collected and stored at $-30^{\circ} \mathrm{C}$ until the hormone assay.

\section{Hormone assays}

The concentration of P4 in oviductal tissues, CL tissues and follicular fluid, and the concentration of E2 in follicular fluid were determined in duplicates using a second-antibody enzyme immunoassay (EIA). All EIA procedures were performed as previously described [22]. The concentrations of E2 in the oviductal tissues were measured using the EIA kit (Detect ${ }^{\circledR}$ SERUM $17 \beta$-ESTRADIOL Enzyme Immunoassay Kit; Funakoshi Co., Ltd., Tokyo, Japan) according to the manufacturer's instructions. Steroid hormone assays were performed after extraction with diethyl ether. P4 recovery rates from the oviduct, CL tissues, and follicular fluid were 83.0, 40.0, and 80.3\%, respectively. E2 recovery rates from the oviduct tissues and follicular fluid were 59.0\% and $79.4 \%$, respectively. The EIA standard curve ranged from 0.05 to $50 \mathrm{ng} / \mathrm{ml}, 2$ to $2,000 \mathrm{pg} / \mathrm{ml}$, and 3.75 to $120 \mathrm{pg} / \mathrm{ml}$ for P4, E2, and E2 EIA kit, respectively. The intra- and inter-assay CVs were 7.2\% and 7.0\% for P4, 9.5\% and $11.8 \%$ for E2, and 3.9 and 5.3\% for E2 EIA kit, respectively.

\section{Total RNA isolation and reverse transcription}

Total RNA isolation was performed using ISOGEN II according to the manufacturer's instructions. RNA concentration and purity were determined using a NanoDrop Spectrophotometer (NanoDrop 2000; Thermo Fisher Scientific, Waltham, MA, U.S.A.). The total RNA was treated with DNase (RQ1 RNase-Free DNase; Promega, Madison, WI, U.S.A.). DNA-free total RNA was reverse transcribed (RT) into complementary DNA (cDNA) using a first strand cDNA synthesis kit (SuperScript VILO Reaction 
Table 1. Primers used in real-time PCR

\begin{tabular}{|c|c|c|c|c|}
\hline Gene & $\begin{array}{l}\text { Primer Sequence } \\
\left(5^{\prime}-3^{\prime}\right)\end{array}$ & $\begin{array}{l}\text { Product size } \\
\text { (bp) }\end{array}$ & $\begin{array}{l}\text { Annealing temperature } \\
\left({ }^{\circ} \mathrm{C}\right)\end{array}$ & Accession number \\
\hline \multirow[t]{2}{*}{ ESR1 } & Forward: TCAGGCTACCATTACGGAGTTT & 120 & 56 & AY538775 \\
\hline & Reverse: GTTTTTATCAATCGTGCACTGG & & & \\
\hline \multirow[t]{2}{*}{ ESR2 } & Forward: CTTCGTGGAGCTCAGCCTGT & 207 & 56 & AF110402 \\
\hline & Reverse: GAGATATTCTTTGTGTTGGAGTTT & & & \\
\hline \multirow[t]{2}{*}{$P G R$} & Forward: TAATCTGTGGGGATGAAGCA & 181 & 58 & AY656812 \\
\hline & Reverse: CAGCACTTTCTAAGGCGACA & & & \\
\hline \multirow[t]{2}{*}{ OVGP1 } & Forward: CCGCTGGACCTTTGTCTTCT & 165 & 61 & NM_001080216 \\
\hline & Reverse: GAAATCCAGGAGTCTGCCCA & & & \\
\hline \multirow[t]{2}{*}{$G P X 4$} & Forward: CGATACGCCGAGTGTGGTTTAC & 261 & 59 & NM_174770 \\
\hline & Reverse: ACAGCCGTTCTTGTCAATGAGG & & & \\
\hline \multirow[t]{2}{*}{ PDIA4 } & Forward: TCGACTACATGATGGAGCAG & 117 & 56 & NM_001045879 \\
\hline & Reverse: CCGACTTAAAGACTCCGATG & & & \\
\hline \multirow[t]{2}{*}{ HSP90B1 } & Forward: TCTCCCTTTGTTGAGCGACT & 250 & 56 & NM_174700 \\
\hline & Reverse: CAGCCTTCTCGATCTTGTCC & & & \\
\hline \multirow[t]{2}{*}{$G A P D H$} & Forward: GAAGCTCGTCATCAATGGAAA & 67 & 59 & U85042 \\
\hline & Reverse: CCACTTGATGTTGGCAGGAT & & & \\
\hline \multirow[t]{2}{*}{$18 S r R N A$} & Forward: AAACGGCTACCACATCCAAG & 142 & 55 & АВ099143.1 \\
\hline & Reverse: TCGCGGAAGGATTTAAAGTG & & & \\
\hline \multirow[t]{2}{*}{$A C T B$} & Forward: CTGGACTTCGAGCAGGAGAT & 140 & 58 & NM_173979.3 \\
\hline & Reverse: AGGAAGGAAGGCTGGAAGAG & & & \\
\hline
\end{tabular}

Mix; Invitrogen, Carlsbad, CA, U.S.A.). The RT conditions consisted of $10 \mathrm{~min}$ of annealing at $25^{\circ} \mathrm{C}, 60$ min of cDNA synthesis at $42^{\circ} \mathrm{C}$, and $5 \mathrm{~min}$ of inactivation at $85^{\circ} \mathrm{C}$. The RT products were stored at $-30^{\circ} \mathrm{C}$ until use for real time polymerase chain reaction (PCR) analysis.

\section{Real-time PCR analysis}

Real-time PCR was performed using a Rotor-Gene Q (QIAGEN, Hilden, Germany) and a commercial kit (SYBR ${ }^{\circledR}$ Premix Ex Taq $^{\text {TM }}$ Tli RNaseH Plus; Takara Bio, Kusatsu, Japan). The primers were designed using the Primer3 software based on bovine sequences. These primer specifications were confirmed by a single expected size band resulted from electrophoresis and monitored by a single melt curve peak in real-time PCR. Three potential reference genes, Glyceraldehyde-3-phosphate dehydrogenase $(G A P D H), 18 \mathrm{~S}$ ribosomal RNA (18S rRNA), and $\beta$-actin $(A C T B)$ were tested using the NormFinder plug-in for Microsoft Excel (MOMA, Aarhus, Denmark). The GAPDH mRNA expression was the most stable among the three genes. Therefore, GAPDH was used as the reference gene and the amounts of mRNA were normalized to GAPDH in this study. The real-time PCR conditions consisted of denaturation at $95^{\circ} \mathrm{C}$ for $15 \mathrm{sec}$, followed by 40 cycles at $95^{\circ} \mathrm{C}$ for $10 \mathrm{sec}$, optimal annealing temperature for each gene for $30 \mathrm{sec}$, and $72^{\circ} \mathrm{C}$ for $40 \mathrm{sec}$ with a final melting curve analysis. All reactions were performed twice under similar setup. All primer sequences, annealing temperature, PCR product sizes, and GeneBank accession numbers are shown in Table 1.

\section{Statistical analysis}

Two-way factorial ANOVA was used to determine the main effects of positional relationship (ipsi vs contra) and region (ampulla vs isthmus), and their interaction. Student's $t$-tests were used to compare the CL size, CL tissue P4 concentration, W1DF size, and intrafollicular E2 concentration of W1DF between the ipsi and contra groups. The relationship between the oviductal E2 concentration and candidate factors (i.e., CL size, CL tissue P4 concentration, W1DF size, follicular fluid E2 concentration) was investigated using the Pearson correlation coefficient. Multiple linear regression was used to determine whether the candidate factors (i.e., CL size, CL tissue P4 concentration, W1DF size, follicular fluid E2 concentration, and the positional relationship between the CL and W1DF [dummy variable; ipsi: 0, contra: 1]) could predict the oviductal E2 concentration. All variables (the candidate factors) were incorporated into the regression model's first step. The Pearson correlation coefficients between the oviductal E2 and P4 concentrations and mRNA expression levels in the oviductal epithelium were calculated for the ampulla and isthmus, respectively. All statistical analyses were performed using StatView Version 5.0 (SAS Institute, Cary, NC, U.S.A.). A level of $P<0.05$ was considered to be statistically significant.

\section{RESULTS}

\section{Effect of positional relationship between CL and W1DF on oviductal E2 and P4 concentrations}

No difference was observed between the oviductal E2 concentrations in ipsi and contra groups, and between that of ampulla and isthmus (Fig. 1A). There was no difference in the P4 concentrations between ipsi and contra groups whereas the oviductal P4 concentration in the ampulla was significantly higher than that of the isthmus (Fig. 1B). 
A

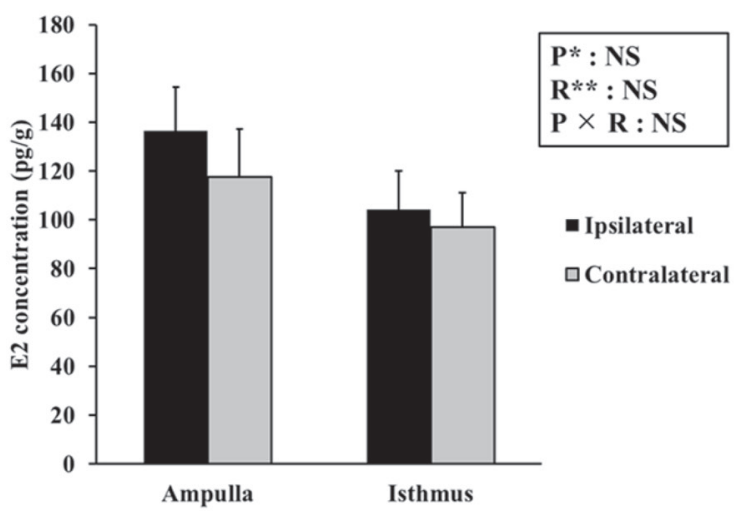

B

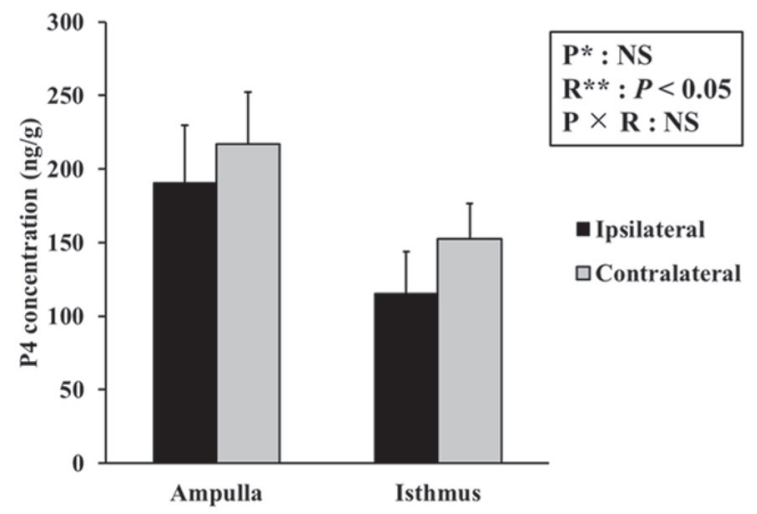

Fig. 1. Oviductal E2 (A) and P4 (B) concentrations of ampulla and isthmus in each positional relationship (i.e., ipsilateral and contralateral). Results are presented as the mean \pm SEM of eight animals. Statistical analysis was performed using two-way factorial ANOVA (*, positional relationship; **, region). NS indicates no significant difference.

Table 2. Characteristics of corpus luteum (CL) and first-wave dominant follicle (W1DF) in the cows used in this study

\begin{tabular}{lccc}
\hline & $\operatorname{Ipsi}^{*}(\mathrm{n}=8)$ & Contra** $\left.^{*} \mathrm{n}=8\right)$ & Total $(\mathrm{n}=16)$ \\
\hline Corpus luteum $(\mathrm{CL})$ & & & \\
Size $(\mathrm{mm})$ & $14.1 \pm 0.5$ & $13.9 \pm 0.5$ & $14.0 \pm 0.3$ \\
P4 $(\mu \mathrm{g} / \mathrm{g}$ tissue $)$ & $9.1 \pm 0.9$ & $8.0 \pm 1.0$ & $8.5 \pm 0.6$ \\
First-wave dominant follicle (W1DF) & & & \\
Size $(\mathrm{mm})$ & $11.2 \pm 0.4$ & $11.9 \pm 0.5$ & $11.5 \pm 0.3$ \\
E2 $(p \mathrm{~g} / \mathrm{m} l)^{* * *}$ & $129.1 \pm 34.1^{\mathrm{a})}$ & $69.2 \pm 16.1^{\mathrm{b})}$ & $99.2 \pm 19.8$ \\
$\mathrm{P} 4(\mathrm{ng} / \mathrm{m} l)^{* * *}$ & $36.4 \pm 8.0$ & $31.9 \pm 5.5$ & $34.1 \pm 4.7$ \\
\hline
\end{tabular}

Mean \pm SEM. *animals with CL and W1DF in the same ovary 3-5 days post-ovulation. **animals with $\mathrm{CL}$ and W1DF in separated ovaries 3-5 days post-ovulation. ***E2 and P4 concentrations in follicular fluid. a, b) Significant difference between ipsi and contra groups $(P<0.05)$.

\section{Size and hormone concentration in $C L$ and W1DF}

The CL and W1DF parameters used in this study are presented in Table 2. No significant differences were found between the ipsi and contra groups with respect to the CL diameter and P4 concentration or the DF diameter and P4 concentration in the follicular fluid. However, the intrafollicular E2 concentration was higher in the ipsi group than in the contra group.

\section{Effect of CL and WIDF functions on oviductal E2 concentration}

No significant correlations were found between the oviductal E2 concentrations of either region and CL size (ampulla: $r=0.17$, $P=0.54$; isthmus: $r=0.09, P=0.75$ ), CL tissue P4 concentration (ampulla: $r=-0.33, P=0.21$; isthmus: $r=-0.24, P=0.37$ ), W1DF size (ampulla: $r=-0.04, P=0.63$; isthmus: $r=-0.17, P=0.53$ ), and follicular fluid E2 concentration (ampulla: $r=0.13, P=0.63$; isthmus: $r=-0.07, P=0.8)$. Multiple regression analysis $(\mathrm{n}=16)$ revealed no predictors of oviductal E2 concentration for the ampulla $\left(R^{2}=0.28, F=0.78, P=0.58\right)$ and isthmus $\left(R^{2}=0.16, F=0.38, P=0.85\right)$.

\section{Relationship between oviductal E2 and P4 concentration and mRNA expressions in oviductal epithelium}

The effect of oviductal E2 and P4 concentration on mRNA expressions in the oviductal epithelium was examined by combining the data of ipsi and contra groups because the positional relationship between CL and W1DF did not influence the oviductal hormone concentration. In the ampulla, $P G R(r=0.55, P<0.05)$ and PDIA4 $(r=0.55, P<0.05)$ mRNA expressions were positively correlated with the oviductal E2 concentration (Table 3$)$ whereas in the isthmus, a significant positive correlation $(r=0.52, P=0.05)$ was found between the ESR1 mRNA expression and oviductal E2 concentration (Table 3). No significant correlations were found between mRNA expressions and oviductal P4 concentration (Table 4).

\section{DISCUSSION}

This study suggests that the local oviductal E2 concentration in the luteal formation phase differently affects the mRNA expressions in the ampulla and isthmus. To the best of our knowledge, this is the first study evaluating the relationship between the 
Table 3. Correlations between oviductal E2 concentration and mRNA expressions in the oviductal epithelium

\begin{tabular}{lccccc}
\hline \multirow{2}{*}{ Gene } & \multicolumn{2}{c}{ Ampulla $(\mathrm{n}=16)$} & & \multicolumn{2}{c}{ Isthmus $(\mathrm{n}=16)$} \\
\cline { 2 - 3 } \cline { 5 - 6 } & $\left.r^{\mathrm{a}}\right)$ & $P$ value & & $r$ & $P$ value \\
\hline ESR1 & 0.27 & 0.33 & & $\mathbf{0 . 5 2}$ & $\mathbf{0 . 0 5}$ \\
ESR2 & 0.42 & 0.42 & & 0.49 & 0.08 \\
PGR & $\mathbf{0 . 5 5}$ & $\mathbf{0 . 0 3}$ & & 0.34 & 0.23 \\
OVGP1 & 0.29 & 0.31 & & -0.00 & 0.99 \\
GPX4 & -0.21 & 0.46 & & -0.13 & 0.71 \\
PDIA4 & $\mathbf{0 . 5 5}$ & $\mathbf{0 . 0 3}$ & & 0.26 & 0.38 \\
HSP90B1 & 0.30 & 0.28 & & 0.14 & 0.64 \\
\hline
\end{tabular}

a) $r$, Pearson correlation coefficient.
Table 4. Correlations between oviductal P4 concentration and mRNA expressions in the oviductal epithelium

\begin{tabular}{lccccc}
\hline \multirow{2}{*}{ Gene } & \multicolumn{2}{c}{ Ampulla $(\mathrm{n}=16)$} & & \multicolumn{2}{c}{ Isthmus $(\mathrm{n}=16)$} \\
\cline { 2 - 3 } \cline { 5 - 6 } & $\left.r^{\mathrm{a}}\right)$ & $P$ value & & $r$ & $P$ value \\
\hline ESR1 & 0.39 & 0.15 & & 0.22 & 0.47 \\
ESR2 & 0.41 & 0.13 & & 0.42 & 0.14 \\
PGR & -0.14 & 0.63 & & 0.34 & 0.25 \\
OVGP1 & 0.27 & 0.34 & & -0.36 & 0.21 \\
GPX4 & -0.33 & 0.24 & & 0.40 & 0.89 \\
PDIA4 & 0.27 & 0.34 & & 0.44 & 0.11 \\
HSP90B1 & 0.31 & 0.28 & & 0.34 & 0.24 \\
\hline
\end{tabular}

a) $r$, Pearson correlation coefficient.

local oviductal E2 concentration and oviductal function in the luteal formation phase.

In the luteal formation phase, the embryo grows in the isthmus, and is transported to the uterus by tubal muscle contraction, ciliary beating, and oviductal fluid flow [20]. It is considered that the oviductal mucosa, which contains proteins secreted by the ampullary epithelial cells, reaches the isthmus and is involved in embryo transport and interaction with the embryo. Therefore, we collected and examined both ampulla and isthmus in the present study.

Because the positional relationship between the dominant follicle and oviduct is associated with the determination of local oviductal E2 concentration in the follicular phase [31], we investigated the effect of the positional relationship between the CL and W1DF on the oviductal E2 concentration in the luteal formation phase. Our results showed that the co-existence of W1DF with CL in the same ovary did not affect the E2 concentration of the CL side oviduct in the luteal formation phase. Furthermore, to search for factors related to the oviductal E2 concentration, we examined the effects of W1DF function, which contributes to the systemic levels of E2, and the CL function, a potential regulator of follicular activity, on the oviductal E2 concentration. The ovarian function in the luteal formation phase was not related to the oviductal E2 concentration. It is possible that the E2 synthetic capacity of W1DF in the luteal formation phase was lower than that in the pre-ovulatory follicle [24, 27] and insufficient to increase the oviductal E2 concentration. In addition, in cattle, the pattern of local blood flow surrounding the reproductive organs changes throughout the estrous cycle [8]. The difference in the oviduct's local blood flow between the estrous and luteal formation phases may be related to the different effects of follicles on the local oviductal E2 concentration. This study could not determine the factors that regulate the local oviductal E2 concentration during the luteal formation phase. Further studies on the regulatory mechanism of oviductal E2 concentration are necessary to clarify the E2 effects on oviductal function.

Because the location of W1DF did not influence the E2 concentration of the CL side oviduct in the luteal formation phase, the relationship between the oviductal E2 concentration and mRNA expressions in the oviductal epithelium was examined by combining the ipsi and contra groups.

On the other hand, regarding the oviductal region, the expressions of 2,287 mRNAs in the bovine oviductal epithelium are different between the ampulla and isthmus [21], suggesting that these mRNAs are related to different oviductal functions. In the study that manipulated the CL function after ovulation to produce two groups with different endocrine milieu during the periovulatory phase, the effects of the steroid hormone milieu on the primary mucosal folds and some oviductal mRNA expressions differed between the ampulla and isthmus [12]. This suggests that the ampulla and isthmus undergo different regulations of the oviductal function by the sex steroid hormones. Therefore, to elucidate the regulatory mechanism of oviductal function by sex steroid hormones, each region should be examined separately.

Our results showed that the $P G R$ mRNA expression was significantly correlated with local E2, but not with P4 concentration, in the ampulla in the luteal formation phase (Tables 3 and 4). It was previously reported that the $P G R$ mRNA expression in the bovine oviductal epithelial cells was upregulated by E2 and downregulated by P4, and was higher in the follicular than in the luteal phase [29]. Interestingly, in this study, the $P G R$ mRNA expression in the bovine ampulla varied with the oviductal E2 concentration in the luteal formation phase under a high P4 condition. The results indicate that the oviductal E2 may be related to the regulation of the $P G R$ mRNA expression in the bovine ampulla in the follicular phase with low $\mathrm{P} 4$ and the luteal formation phase with high $\mathrm{P} 4$.

The ESR1 mRNA expression in the isthmus increases in the follicular phase, whereas in the ampulla, it does not change throughout the estrous cycle [29]. Although several in vitro studies have investigated the regulation of the oviductal ESR1 mRNA expression by E2, the results remain controversial. For example, one study showed that the expression of ESR1 mRNA was upregulated by E2 [29] whereas another study observed no change [26]. Our in vivo results show that the oviductal ESR1 mRNA expression in the luteal formation phase varied with the oviductal E2 concentration in the isthmus but not in the ampulla (Table 3). Therefore, further studies using culture models and considering the estrus cycle and oviductal region are required to investigate the regulation mechanism of the oviductal ESR1 mRNA expression.

In bovine oviductal epithelial cells, the OVGP1, GPX4, PDIA4, and HSP90B1 mRNA expressions are thought to be under the $\mathrm{E} 2$ regulation $[4,19]$. In addition, these four genes are related to the formation of the optimal oviductal environment for fertilization and embryonic development $[4,5,20]$. Therefore, these genes are considered to be appropriate for evaluating the role of oviductal E2 on the oviductal function. However, in this study, no E2-related differences were found in the $O V G P 1$, GPX4, and 
HSP9OB1 mRNA expressions of oviductal epithelial cells in the luteal formation phase (Tables 3 and 4). In swine, the oviductal OVGP1 mRNA expression was shown to be facilitated by E2 treatment, an effect prevented by P4 treatment [6]. In this study, the oviductal P4 concentration was approximately ten times higher than the previously reported P4 levels in the follicular phase $(10-30 \mathrm{ng} / \mathrm{g}$ tissue) [18]. This difference suggests that in this study, the effects of E2 on the oviductal OVGP1 mRNA as well as GPX4 and HSP90B1 expressions are prevented by the high oviductal P4 concentration during the luteal formation phase. However, our results showed that the PDIA4 mRNA expression in the ampulla was positively correlated with the oviductal E2 concentration (Table 3). This suggests that the oviductal E2 is related to the PDIA4 mRNA expression in the ampulla in the luteal formation phase. The bovine oviductal epithelium contains two cell types (i.e., ciliated and secretory cells). In general, the ampulla has a higher population of secretory cells, which are useful for protein synthesis and secretion, than isthmus [5]. PDIA4 is related to the biological process of protein secretion and the PDIA4 expression is known to be upregulated in the follicular phase with a high E2 level [4], in which the secretory activity of oviductal epithelium increases. Our results therefore suggest that the oviductal E2 is related to the secretory function of ampulla in the luteal formation phase.

The correlation of oviductal E2 concentration with some mRNA expressions in the ampulla and isthmus indicates that oviductal E2 may be a potential regulator of the oviductal function in the luteal formation phase. Furthermore, in this study, the oviductal $P G R$ expression was correlated with the oviductal E2 concentration, thereby suggesting that E2 alters the sensitivity of the bovine oviduct to P4 in the luteal formation phase. It is therefore possible that in the luteal formation phase, the oviductal function is regulated by an interaction between the P4 secreted by the growing CL and E2 secreted by the W1DF. However, the cell types of the oviductal epithelium were not examined in the present study. The ratio of secretory and ciliary cells in the oviductal epithelium changes throughout the estrous cycle [14] and some protein expressions (i.e., PGR and ESR1) are known to be different between the secretory and ciliary cells [15]. Therefore, our results may indicate that the mRNA expressions of oviductal cells were changed or the ratio of oviductal epithelial cells that have different mRNA expressions was changed by the local E2 in the luteal formation phase. To clarify the regulation of the mRNA expressions of oviductal epitheliums by sex steroid hormone, it is necessary to examine the mRNA expressions in the oviductal epithelium with respect to the ratio of secretory and ciliary cells.

Overall, our findings suggest that, during the luteal formation phase, the local oviductal E2 affects the oviductal functions in a concentration-dependent manner. Moreover, E2 may be related to the sensitivity of oviductal epithelium to P4. Therefore, during the luteal formation phase, the oviductal function may be characterized by the interaction between the oviductal E2 and P4 concentration.

ACKNOWLEDGMENT. We would like to thank the Obihiro Meat Center (Obihiro, Hokkaido, Japan) for providing bovine reproductive tracts.

\section{REFERENCES}

1. Arosh, J. A., Parent, J., Chapdelaine, P., Sirois, J. and Fortier, M. A. 2002. Expression of cyclooxygenases 1 and 2 and prostaglandin E synthase in bovine endometrial tissue during the estrous cycle. Biol. Reprod. 67: 161-169. [Medline] [CrossRef]

2. Avilés, M., Coy, P. and Rizos, D. 2015. The oviduct: A key organ for the success of early reproductive events. Anim. Front. 5: 25-31. [CrossRef]

3. Ayalon, N. 1978. A review of embryonic mortality in cattle. J. Reprod. Fertil. 54: 483-493. [Medline] [CrossRef]

4. Bauersachs, S., Rehfeld, S., Ulbrich, S. E., Mallok, S., Prelle, K., Wenigerkind, H., Einspanier, R., Blum, H. and Wolf, E. 2004. Monitoring gene expression changes in bovine oviduct epithelial cells during the oestrous cycle. J. Mol. Endocrinol. 32: 449-466. [Medline] [CrossRef]

5. Binelli, M., Gonella-Diaza, A. M., Mesquita, F. S. and Membrive, C. M. B. 2018. Sex steroid-mediated control of oviductal function in cattle. Biology (Basel) 7: 15. [Medline]

6. Buhi, W. C., Alvarez, I. M., Choi, I., Cleaver, B. D. and Simmen, F. A. 1996. Molecular cloning and characterization of an estrogen-dependent porcine oviductal secretory glycoprotein. Biol. Reprod. 55: 1305-1314. [Medline] [CrossRef]

7. Echternkamp, S. E. and Hansel, W. 1973. Concurrent changes in bovine plasma hormone levels prior to and during the first postpartum estrous cycle. J. Anim. Sci. 37: 1362-1370. [Medline] [CrossRef]

8. Ford, S. P. and Chenault, J. R. 1981. Blood flow to the corpus luteum-bearing ovary and ipsilateral uterine horn of cows during the oestrous cycle and early pregnancy. J. Reprod. Fertil. 62: 555-562. [Medline] [CrossRef]

9. Ghersevich, S., Massa, E. and Zumoffen, C. 2015. Oviductal secretion and gamete interaction. Reproduction 149: R1-R14. [Medline] [CrossRef]

10. Ginther, O. J., Knopf, L. and Kastelic, J. P. 1989. Temporal associations among ovarian events in cattle during oestrous cycles with two and three follicular waves. J. Reprod. Fertil. 87: 223-230. [Medline] [CrossRef]

11. Gonella-Diaza, A. M., Andrade, S. C., Sponchiado, M., Pugliesi, G., Mesquita, F. S., Van Hoeck, V., Strefezzi, R. F., Gasparin, G. R., Coutinho, L. L. and Binelli, M. 2015. Size of the ovulatory follicle dictates spatial differences in the oviductal transcriptome in cattle. PLoS One 10: e0145321. [Medline] [CrossRef]

12. Gonella-Diaza, A. M., Mesquita, F. S., da Silva, K. R., de Carvalho Balieiro, J. C., Dos Santos, N. P., Pugliesi, G., de Francisco Strefezzi, R. and Binelli, M. 2017. Sex steroids modulate morphological and functional features of the bovine oviduct. Cell Tissue Res. 370: 319-333. [Medline] [CrossRef]

13. Ireland, J. J., Murphee, R. L. and Coulson, P. B. 1980. Accuracy of predicting stages of bovine estrous cycle by gross appearance of the corpus luteum. J. Dairy Sci. 63: 155-160. [Medline] [CrossRef]

14. Ito, S., Kobayashi, Y., Yamamoto, Y., Kimura, K. and Okuda, K. 2016. Remodeling of bovine oviductal epithelium by mitosis of secretory cells. Cell Tissue Res. 366: 403-410. [Medline] [CrossRef]

15. Kenngott, R. A., Vermehren, M., Sauer, U., Ebach, K. and Sinowatz, F. 2011. Cellular expression and localization of estrogen receptor $\alpha$ and progesterone receptor mRNA in the bovine oviduct combining laser-assisted microdissection, quantitative PCR, and in situ hybridization. $J$. Histochem. Cytochem. 59: 312-327. [Medline] [CrossRef]

16. Killian, G. J., Chapman, D. A., Kavanaugh, J. F., Deaver, D. R. and Wiggin, H. B. 1989. Changes in phospholipids, choline, and protein content of 
cow oviductal fluid during the cow estrous cycle. J. Reprod. Fertil. 86: 419-426. [Medline] [CrossRef]

17. Kobayashi, Y., Wakamiya, K., Kohka, M., Yamamoto, Y. and Okuda, K. 2013. Summer heat stress affects prostaglandin synthesis in the bovine oviduct. Reproduction 146: 103-110. [Medline] [CrossRef]

18. Kowalik, M. K., Martyniak, M., Rekawiecki, R. and Kotwica, J. 2016. Expression and immunolocalization of membrane progesterone receptors in the bovine oviduct. Domest. Anim. Endocrinol. 55: 83-96. [Medline] [CrossRef]

19. Lapointe, J., Kimmins, S., Maclaren, L. A. and Bilodeau, J. F. 2005. Estrogen selectively up-regulates the phospholipid hydroperoxide glutathione peroxidase in the oviducts. Endocrinology 146: 2583-2592. [Medline] [CrossRef]

20. Li, S. and Winuthayanon, W. 2017. Oviduct: roles in fertilization and early embryo development. J. Endocrinol. 232: R1-R26. [Medline] [CrossRef]

21. Maillo, V., de Frutos, C., O’Gaora, P., Forde, N., Burns, G. W., Spencer, T. E., Gutierrez-Adan, A., Lonergan, P. and Rizos, D. 2016. Spatial differences in gene expression in the bovine oviduct. Reproduction 152: 37-46. [Medline] [CrossRef]

22. Miyamoto, A., Okuda, K., Schweigert, F. J. and Schams, D. 1992. Effects of basic fibroblast growth factor, transforming growth factor-beta and nerve growth factor on the secretory function of the bovine corpus luteum in vitro. J. Endocrinol. 135: 103-114. [Medline] [CrossRef]

23. Nishigai, M., Kamomae, H., Tanaka, T. and Kaneda, Y. 2002. Improvement of pregnancy rate in Japanese Black cows by administration of hCG to recipients of transferred frozen-thawed embryos. Theriogenology 58: 1597-1606. [Medline] [CrossRef]

24. Nishimoto, H., Hamano, S., Hill, G. A., Miyamoto, A. and Tetsuka, M. 2009. Classification of bovine follicles based on the concentrations of steroids, glucose and lactate in follicular fluid and the status of accompanying follicles. J. Reprod. Dev. 55: 219-224. [Medline] [CrossRef]

25. Rantala, M. H., Mutikainen, M., Schuler, G., Katila, T. and Taponen, J. 2014. Endometrial expression of progesterone, estrogen, and oxytocin receptors and of 20 $\alpha$-hydroxysteroid dehydrogenase and cyclooxygenase II 2 and 5 days after ovulation in induced short and normal estrous cycles in dairy cows. Theriogenology 81: 1181-1188. [Medline] [CrossRef]

26. Rottmayer, R., Ulbrich, S. E., Kölle, S., Prelle, K., Neumueller, C., Sinowatz, F., Meyer, H. H., Wolf, E. and Hiendleder, S. 2006. A bovine oviduct epithelial cell suspension culture system suitable for studying embryo-maternal interactions: morphological and functional characterization. Reproduction 132: 637-648. [Medline] [CrossRef]

27. Smith, J. F., Fairclough, R. J., Payne, E. and Peterson, A. J. 1975. Plasma hormone levels in the cow. N. Z. J. Agric. Res. 18: 123-129. [CrossRef]

28. Takahashi, H., Haneda, S., Kayano, M. and Matsui, M. 2016. Differences in progesterone concentrations and mRNA expressions of progesterone receptors in bovine endometrial tissue between the uterine horns ipsilateral and contralateral to the corpus luteum. J. Vet. Med. Sci. 78: 613-618. [Medline] [CrossRef]

29. Ulbrich, S. E., Kettler, A. and Einspanier, R. 2003. Expression and localization of estrogen receptor alpha, estrogen receptor beta and progesterone receptor in the bovine oviduct in vivo and in vitro. J. Steroid Biochem. Mol. Biol. 84: 279-289. [Medline] [CrossRef]

30. Wijayagunawardane, M. P., Kodithuwakku, S. P., Yamamoto, D. and Miyamoto, A. 2005. Vascular endothelial growth factor system in the cow oviduct: a possible involvement in the regulation of oviductal motility and embryo transport. Mol. Reprod. Dev. 72: 511-520. [Medline] [CrossRef]

31. Wijayagunawardane, M. P., Miyamoto, A., Cerbito, W. A., Acosta, T. J., Takagi, M. and Sato, K. 1998. Local distributions of oviductal estradiol, progesterone, prostaglandins, oxytocin and endothelin-1 in the cyclic cow. Theriogenology 49: 607-618. [Medline] [CrossRef]

32. Yániz, J. L., Lopez-Gatius, F., Santolaria, P. and Mullins, K. J. 2000. Study of the functional anatomy of bovine oviductal mucosa. Anat. Rec. 260: 268-278. [Medline] [CrossRef] 